\title{
Chemical Composition and Antimicrobial Activities of Cold-Pressed Oils Obtained From Nettle, Radish and Pomegranate Seeds
}

\author{
Ergin Murat ALTUNER ${ }^{1 *}$, Talip ÇETER ${ }^{1}$, Mahmut GÜR ${ }^{2}$, Kerim GÜNEY $^{3}$, Bayram KIRAN ${ }^{4}$, Hana \\ Ealoma AKWIETEN ${ }^{4}$, Sana I. SOULMAN ${ }^{4}$ \\ ${ }^{1}$ Kastamonu University, Faculty of Science and Arts, Department of Biology, Kastamonu, TURKEY \\ ${ }^{2}$ Kastamonu University, Faculty of Forestry, Department of Forest Industrial Engineering \\ Kastamonu, TURKEY \\ ${ }^{3}$ Kastamonu University, Faculty of Forestry, Department of Forest Engineering \\ Kastamonu, TURKEY \\ ${ }^{4}$ Kastamonu University, Faculty of Engineering and Architecture, Department of Genetic and \\ Bioengineering, Kastamonu, TURKEY \\ *Corresponding author: ergin.murat.altuner@gmail.com
}

Received Date: 21.02.2018

Accepted Date: 28.06.2018

\section{Abstract}

Aim of study: The aim of this study is to put forward the antimicrobial activity of cold pressed oils obtained from seeds of nettle (Urtica dioica), radish (Raphanus sativus) and pomegranate (Punica granatum).

Material and Methods: Oils of these seeds were analysed for their antibacterial and antifungal activities by the disk diffusion and MIC tests against fifteen microorganisms, Staphylococcus epidermidis DSMZ 20044, Staphylococcus aureus ATCC 25923, Salmonella typhimurium SL 1344, Salmonella kentucky, Salmonella infantis, Salmonella enteritidis, Pseudomonas fluorescens P1 ATCC 13075, Pseudomonas aeruginosa DSMZ 50071, Klebsiella pneumoniae, Escherichia coli ATCC 25922, Enterococcus faecium, Enterococcus faecalis ATCC 29212, Enterobacter aerogenes ATCC 13048, Candida albicans DSMZ 1386 and Bacillus subtilis DSMZ 1971. The results were compared against 11 standard antibiotics, which are cefazolin, clindamycin, chloramphenicol, ciprofloxacin, amoxicillin/clavulanic acid, sulfamethoxazole/trimethoprim, ceftriaxone, gentamicin, ampicillin, cephalothin, cefuroxime and vancomycin. The extracts were also chemically analysed by using GC-MS.

Main results: As a result, radish oil is observed to be active against all microorganisms with the highest activity, where nettle oil is active against all microorganisms except for S. epidermidis. The lowest activity was observed in pomegranate oil.

Highlights: The results of the study clearly puts forward that oils obtained from nettle, radish and pomegranate could have a possible medicinal use.

Keywords: Chemical Composition, Cold-Pressed Oil, Antimicrobial Activity, Nettle, Radish, Pomegranate

\section{Isırgan, Turp ve Nar Tohumlarından Soğuk-Sıkım Yöntemi ile Elde}

\section{Edilen Yağların Kimyasal Bileşimi ve Antimikrobiyal Aktiviteleri}

\section{Öz}

Çalışmanın amacı: Bu çalışmanın amacı ısırgan (Urtica dioica), turp (Raphanus sativus) ve nar (Punica granatum) tohumlarından elde edilen soğuk sıkım yağların antimikrobiyal etkilerinin ortaya koymaktır.

Materyal ve Yöntem: Bu tohumların yağları, Staphylococcus epidermidis DSMZ 20044, Staphylococcus aureus ATCC 25923, Salmonella typhimurium SL 1344, Salmonella kentucky, Salmonella infantis, Salmonella enteritidis, Pseudomonas fluorescens P1 ATCC 13075, Pseudomonas aeruginosa DSMZ 50071, Klebsiella pneumoniae, Escherichia coli ATCC 25922, Enterococcus faecium, Enterococcus faecalis ATCC 29212, Enterobacter aerogenes ATCC 13048, Candida albicans DSMZ 1386 ve Bacillus subtilis DSMZ 1971 gibi 15 mikroorganizmaya karşı disk difüzyon metodu ve MIKK testi kullanılarak, antimikrobiyal aktiviteleri açısından araştırılmıştır. Sonuçlar sefazolin, klindamisin, kloramfenikol, siprofloksasin, amoksisilin/klavulanik asit, sülfametoksazol/trimetoprim, seftriakson, gentamisin, ampisilin, sefalotin, sefuroksim ve vankomisin olmak üzere 11 standart antibiyotik ile karşılaştırılmıştır. Ekstraktlar ayrıca GC-MS kullanılarak kimyasal olarak analiz edilmiştir.

Sonuçlar: Sonuç olarak, turp yağının en yüksek aktiviteyi göstererek bütün mikroorganizmalara, ısırgan yağının ise $S$. epidermidis hariç bütün mikroorganizmalara etkili olduğu gözlenmiştir. En düşük aktivite ise nar yağında gözlenmiştir.

Önemli vurgular: Çalışmanın sonuçları, açık bir şekilde, ısırgan otu, turp ve nardan elde edilen yağların destekleyici sağlık ürünü olarak ve ilave çalışmalarla medikal amaçlı olarak da kullanılabileceğini ortaya koymaktadır.

Anahtar Kelimeler: Kimyasal Kompozisyon, Soğuk Pres Yağ, Antimikrobiyal Aktivite, Isırgan, Turp, Nar 


\section{Introduction}

Using natural plant derived products against diseases is as old as human history. Today scientists are trying to analyse the anti-infective potential of these herbal remedies (Abbasi, Khan, Ahmad, Jahan \& Sultana, 2010). These studies triggered the development of several antimicrobial agents rooted from natural products (Andrews, 2003; Ates and Erdogrul, 2003; Altuner, Cetin \& Cökmüs, 2010a and b).

Today it is generally proposed that there is a remarkable progress in human medicine as a result of these scientific studies, but today especially in the countries, which are developing, still several diseases related to bacteria, virus and fungus are causing severe problems for the public health due to the extensive antibiotic resistance of microorganisms (Okeke et al., 2005; Cos, Vlietinck, Vanden Berghe \& Maes, 2006).

"The World Health Report" which was published in 2007 by WHO (World Health Organization) declared that the antibiotic resistance due to the microbial evolution possibly have a great impact on human beings for the next century. And this underlined idea was mentioned as the most potential serious problem for the public health (WHO, 2007; Syed, Syed, \& Oh, 2010; Altuner et al., 2011a and b).

With the aim of preventing to spread these microorganisms, which are resistant to commercially used antimicrobials, characterization of new antimicrobial agents is proposed as the major aim for the scientists (Özkinali, Şener, Gür, Güney \& Olgun, 2017; Canlı, Şimşek, Yetgin \& Altuner, 2017).

Nettle (Urtica dioica) is commonly distributed in North America and Europe, and found in some parts of Asia and North Africa too. In some areas in the world some naturalized groups are also known to be present. Nettle plants are known to be collected for several reasons since ancient times, which are still being collected not only for culinary purposes but also for healing diseases too. In addition to that these plants are also known to have several medicinal properties, such as extracts of nettle leaves are still commonly used for several purposes. In addition, the leaves covered with needle like hairs are applied to skin against rheumatism traditionally. It was previously proven that leaves of this plant can be used against inflammation. Also the root extract can be used in BPH (benign prostate hyperplasia) (Kew Science, 2017a).

Radish (Raphanus sativus) is known to be rooted from East-Mediterranean lands. It is known that this plant was one of the main foods produced in Egypt about 2.000 BC's. Today radish cultivars are found in different ecological environments. There are several records showing that starting from very early times of human history this plant has been cultivated. The taproot is mostly consumed without cooking. Black radishes are also commonly used especially in EasternEuropean foods (Kew Science, 2017b).

There are several studies showing that pomegranate (Punica granatum) is originated from the lands falling into today's North India and Iran, and it is shown that cultivation of this plant has been started in Mediterranean area very long time ago. Pomegranate plant has several uses, such as production of tannins to treat leathers, inks and dyes, and also for juice. In addition, it is also used for the production of different medicines against several diseases. It is also worth to mention that in many cultures pomegranate, especially pomegranate fruit, is accepted to be the symbol of fertility (Rieger, 2017).

There are several ways of uses especially for the oil obtained from pomegranate seed, such as against aging of the skin, reversing the damage in the skin and healing the wounds by triggering cell regeneration, protecting skin from UV and thus decreasing the risk of skin cancer, controlling oil and acne production of the skin, calming psoriasis and eczema, soothing redness and irritation of the skin, improving the health of the scalp and hairs (Health Beckon, 2014).

In this study, cold-pressed seed oils of Urtica dioica, Raphanus sativus and Punica granatum are tested for their antimicrobial activity by MIC and the disk diffusion tests. In addition to that the chemical composition of these oils were determined through a GCMS analysis. 


\section{Materials and Method \\ Plant samples}

Urtica dioica, Raphanus sativus and Punica granatum seeds were purchased from a local company (Özşen Lokman Hekim).

\section{Oil extraction}

The oil was obtained through a cold-press production (MP-001 Screw Press, Turkey). One kilogram of each seed was pressed, filtered and allowed to stand overnight. After 24 hours the upper clear layer of oil was separated through a separation funnel. Obtained oils were kept in cold $\left(4^{\circ} \mathrm{C}\right)$ and dark until used in test. The yield percentage for all plant samples were found to be $50 \%$ $(\mathrm{w} / \mathrm{w})$ for $U$. dioica, 30\% (w/w) for $R$. sativus and $10 \%(\mathrm{w} / \mathrm{w})$ for $P$. granatum.

\section{Microorganisms}

Several Gram positive and Gram negative microorganisms were selected to analyse the activity of the oils. The fifteen microorganisms used in this study are Staphylococcus epidermidis DSMZ 20044, Staphylococcus aureus ATCC 25923, Salmonella typhimurium SL 1344, Salmonella kentucky, Salmonella infantis, Salmonella enteritidis, Pseudomonas fluorescens P1 ATCC 13075, Pseudomonas aeruginosa DSMZ 50071, Klebsiella pneumoniae, Escherichia coli ATCC 25922, Enterococcus faecium, Enterococcus faecalis ATCC 29212, Enterobacter aerogenes ATCC 13048, Candida albicans DSMZ 1386 and Bacillus subtilis DSMZ 1971.

\section{Inoculum}

Microorganisms used in this study were cultured in line with their requirements as stated in some previous studies (Altuner and Çetin, 2009; Altuner and Canli, 2012; Canlı Altuner \& Akata, 2015).

For inoculum, microorganisms were suspended in sterile physiological saline solution (Canlı, Altuner, Akata, Türkmen \& Üzek, 2016; Canll, Yetgin, Akata \& Altuner, 2016a and b; Canl1, Yetgin, Akata \& Altuner, 2017a) and to adjust equal the number of the colonies in the solution, $0.5 \mathrm{McF}$ arland standard was used (Hammer, Carson \& Riley, 1999; Altuner, Akata \& Canli, 2012a and b).

\section{Disk diffusion (DD) method}

For DD test previously mentioned methodologies were used (Andrews, 2003; Altuner, Ceter \& Islek, 2010; Canli et al, 2014). Petri dishes having $9 \mathrm{~mm}$ dimensions, which contain $25 \mathrm{~mL}$ of Mueller Hinton Agar were used in order to standardize the work (Ilhan, Savaroğlu, Çolak, Iscen \& Erdemgil, 2006; Canl1, Yetgin, Akata \& Altuner, 2016c). Five and 15 microliters of oils were transferred to sterile antibiotic disks (SAD) and then they were kept at $40{ }^{\circ} \mathrm{C}$ for $24 \mathrm{~h}$ in aseptic conditions (Canl1, Akata \& Altuner, 2016). Microorganism suspensions were inoculated to agar medium (Mueller Hinton) and left in aseptic conditions for 2-3 minutes before applying oil loaded disks as described in the previous studies Altuner and Akata (2010). Inhibition zones were defined in $\mathrm{mm}$ by the method mentioned by Altuner, Canli \& Akata (2014).

\section{Determination of MIC}

The MIC values for all oil samples were identified as stated previously (Balouiri, Sadiki \& Ibnsouda, 2016). The concentration range was between 100 to $0.195 \mu \mathrm{g} / \mathrm{mL}$.

\section{Determination of chemical composition by GC-MS}

For determination of the chemical composition of oil samples the methodology mentioned previously was used (Canl, Yetgin, Akata \& Altuner, 2017b).

\section{Controls}

Empty SAD was used as negative controls for disk diffusion test and sterilized broth medium for MIC test. In addition, microorganisms were inoculated in Mueller Hinton broth in order to control the viability of each microorganism.

As positive controls eleven standard antibiotics, which are cefazolin, clindamycin, chloramphenicol, ciprofloxacin, amoxicillin / clavulanic acid, sulfamethoxazole / trimethoprim, ceftriaxone, gentamicin, ampicillin, cephalothin, cefuroxime and vancomycin are used.

\section{Statistics}

The tests were replicated three times. All the results given were mentioned as the mean 
of the parallels. The statistical analysis were conducted as mentioned by Altuner (2011) with a $p$ value of 0.05 .

\section{Results and Discussion}

According to the GC-MS results the most abundant component determined for $U$. dioica, $R$. sativus and $P$. granatum oils are found to be $34 \%, 20 \%$ and $19 \%$ in scanning of essential oils and 14\%, 35\% and 32\% in scanning of fatty acid, respectively and the list of all main components for $U$. dioica, $R$. sativus and $P$. granatum oils are presented in Table 1 and Table 2.

GC-MS results showed that the major essential oils of $U$. dioica oil contains (Z,Z)9,12-octadecadienoyl chloride (4.88\%), 9octadecenoic acid, 1,2,3-propanetriyl ester, (E,E,E)- (11.25\%), linolenic acid, 2-hydroxy1-(hydroxymethyl)ethyl ester (Z,Z,Z)(3.00\%), cis-9-hexadecenal (33.81\%), tridecanedial $(9.56 \%)$, hexadecanoic acid, 2 - hydroxy-1,3-propanediyl ester (13.45\%), (Z,Z)-9,12-octadecadien-1-ol (5.81\%) as the main components as essential oils; $R$. sativus contains 9,12-octadecadienoyl chloride, (Z,Z)- (3.01\%), 9-octadecenoic acid, 1,2,3propanetriyl ester, (E,E,E)- (7.55\%), di-(9octadecenoyl)-glycerol (3.53\%), cis-9hexadecenal (58.65\%), hexadecanoic acid, 2hydroxy-1,3-propanediyl ester (18.25\%) and $P$. granatum contains (Z,Z)-9,12octadecadienoyl chloride (7.85\%), 9octadecenoic acid, 1,2,3-propanetriyl ester, (E,E,E)- (13.69\%), di-(9-octadecenoyl)glycerol $\quad(3.06 \%), \quad$ cis-9-hexadecenal $(61.77 \%)$. The main essential oil components of the oils obtained from three plant samples are given in Table 1 .

Table 1 clearly shows that cis-9hexadecenal is the most abundant essential oil in all by three plant oils.

Table 1. The major essential oils

\begin{tabular}{|c|c|c|c|c|c|}
\hline U. dioica & $\%$ & R. sativus & $\%$ & P. granatum & $\%$ \\
\hline cis-9-hexadecenal & 33.81 & cis-9-hexadecenal & 58.65 & cis-9-hexadecenal & 61.77 \\
\hline $\begin{array}{l}\text { hexadecanoic acid, 2- } \\
\text { hydroxy-1,3-propanediyl } \\
\text { ester }\end{array}$ & 13.45 & $\begin{array}{l}\text { hexadecanoic acid, 2- } \\
\text { hydroxy-1,3-propanediyl } \\
\text { ester }\end{array}$ & 18.25 & $\begin{array}{l}\text { 9-octadecenoic acid, } \\
\text { 1,2,3-propanetriyl ester, } \\
\text { (E,E,E)- }\end{array}$ & 13.69 \\
\hline $\begin{array}{l}\text { 9-octadecenoic acid, 1,2,3- } \\
\text { propanetriyl ester, (E,E,E)- }\end{array}$ & 11.25 & $\begin{array}{l}\text { 9-octadecenoic acid, 1,2,3- } \\
\text { propanetriyl ester, } \\
\text { (E,E,E)- }\end{array}$ & 7.55 & $\begin{array}{l}\text { (Z,Z)-9,12- } \\
\text { octadecadienoyl chloride }\end{array}$ & 7.85 \\
\hline tridecanedial & 9.56 & $\begin{array}{l}\text { di-(9-octadecenoyl)- } \\
\text { glycerol }\end{array}$ & 3.53 & $\begin{array}{l}\text { di-(9-octadecenoyl)- } \\
\text { glycerol }\end{array}$ & 3.06 \\
\hline (Z,Z)-9,12-octadecadien-1-ol & 5.81 & $\begin{array}{l}\text { 9,12-octadecadienoyl } \\
\text { chloride, }(\mathrm{Z}, \mathrm{Z}) \text { - }\end{array}$ & 3.01 & & \\
\hline $\begin{array}{l}\text { (Z,Z)-9,12-octadecadienoyl } \\
\text { chloride }\end{array}$ & 4.88 & & & & \\
\hline $\begin{array}{l}\text { Linolenic acid, 2-hydroxy-1- } \\
\text { (hydroxymethyl)ethyl ester } \\
\text { (Z,Z,Z)- }\end{array}$ & 3.00 & & & & \\
\hline
\end{tabular}

Table 2. The major fatty acids

\begin{tabular}{lclclc}
\hline \multicolumn{1}{c}{$\boldsymbol{U}$. dioica } & $\boldsymbol{\%}$ & \multicolumn{1}{c}{$\boldsymbol{R}$. sativus } & \% & \multicolumn{1}{c}{$\boldsymbol{P}$. granatum } & \% \\
\hline $\begin{array}{l}\text { 9,12-Octadecadienoic } \\
\text { acid (Z,Z)-, methyl ester }\end{array}$ & 38.87 & $\begin{array}{l}\text { 13-docosenoic acid, } \\
\text { methyl ester }\end{array}$ & 25.40 & $\begin{array}{l}\text { methyl-9.cis.,11.trans.t,13.trans.- } \\
\text { octadecatrienoate }\end{array}$ & 55.93 \\
\hline $\begin{array}{l}\text { 9-octadecenoic acid (Z)- } \\
\text { methyl ester }\end{array}$ & 14.34 & $\begin{array}{l}\text { 6-octadecenoic acid, } \\
\text { methyl ester, (Z)- }\end{array}$ & 17.22 & $\begin{array}{l}\text { 9-octadecenoic acid (Z)-, methyl } \\
\text { ester }\end{array}$ & 6.42 \\
\hline $\begin{array}{l}\text { cyclohexanecarboxylic } \\
\text { acid, decyl ester }\end{array}$ & 22.18 & $\begin{array}{l}\text { 11-Eicosenoic acid, } \\
\text { methyl ester }\end{array}$ & 8.54 & $\begin{array}{l}\text { tricyclo[8.6.0.0(2,9)]hexadeca- } \\
\text { 3,15-diene, trans-2,9-anti-9,10-cis- } \\
1,10\end{array}$ & 6.40 \\
\hline $\begin{array}{l}\text { Methyl 5,11,14- } \\
\text { eicosatrienoate }\end{array}$ & 9.79 & $\begin{array}{l}\text { 9,12-octadecadienoic } \\
\text { acid (Z,Z)-, methyl } \\
\text { ester }\end{array}$ & 8.30 & $\begin{array}{l}\text { (Z,Z)-9,12-octadecadienoic acid } \\
\text { methyl ester }\end{array}$ & 5.75 \\
\hline $\begin{array}{l}\text { hexadecanoic acid, } \\
\text { methyl ester }\end{array}$ & 4.32 & $\begin{array}{l}\text { di-(9octadecenoyl)- } \\
\text { glycerol }\end{array}$ & 4.14 & di-(9-octadecenoyl)-glycerol & 4.62 \\
\hline
\end{tabular}


GC-MS results showed that the major fatty acids of $U$. dioica oil contains hexadecanoic acid, methyl ester (4.32\%), 9,12-Octadecadienoic acid (Z,Z)-, methyl ester (38.87\%), 9-octadecenoic acid (Z)-, methyl ester (14.34\%), Methyl 5,11,14eicosatrienoate (9.79\%), cyclohexane carboxylic acid, decyl ester (22.18\%); $R$. sativus contains 9,12-octadecadienoic acid (Z,Z)-, methyl ester (8.30\%), 6-octadecenoic acid, methyl ester, (Z)- (17.22\%), 11Eicosenoic acid, methyl ester (8.54\%), di(9octadecenoyl)-glycerol (4.14\%), 13docosenoic acid, methyl ester $(25.40 \%)$ and $P$. granatum contains (Z,Z)-9,12octadecadienoic acid methyl ester $(5.75 \%)$, 9-octadecenoic acid (Z)-, methyl ester (6.42\%), methyl-9.cis.,11.trans.t,13.trans.octadecatrienoate $\quad(55.93 \%), \quad$ di-(9octadecenoyl)-glycerol (4.62\%), tricyclo[8.6.0.0(2,9)]hexadeca-3,15-diene, trans-2,9-anti-9,10-cis-1,10 (6.40\%). The main fatty acid components of the oils obtained from three plant samples are given in Table 2.

Table 2 clearly presents that the most abundant fatty acids of each plant oil is different, which are 9,12-octadecadienoic acid (Z,Z)-, methyl ester (38.87\%) for $U$. dioica, 13-docosenoic acid, methyl ester (25.40\%) for $R$. sativus and methyl9.cis.,11.trans.t,13.trans.-octadecatrienoate (55.93\%) for P. granatum.

The results for disk diffusion test of $U$. dioica, $R$. sativus and $P$. granatum oils are given in Table 3 and the results for standard antibiotic disks are given in Table 4 too.

The MIC values observed for $U$. dioica, $R$. sativus and $P$. granatum are given in Table 5.

According to the results, $U$. dioica seed oil was observed to be active all bacteria and fungi except for S. epidermidis and the MIC values were observed to be between 12.5 and $25 \mu \mathrm{g} / \mathrm{mL}$. Although an activity was observed against $P$. aeruginosa in disk diffusion test, no MIC value can be identified. This could be due to $U$. dioica seed oil presented a static activity, rather than cidal activity. In order to understand this, further analysis should be conducted.

$R$. sativus seed oil was observed to be active all bacteria and fungi, and the MIC values were observed to be between 12.5 and $25 \mu \mathrm{g} / \mathrm{mL}$.

$P$. granatum showed to be active against $S$. epidermidis, S. aureus, S. kentucky, $S$. enteritidis, $P$. fluorescens, $P$. aeruginosa, $K$. pneumoniae, E. coli, E. faecium and $E$. aerogenes and the MIC values for these bacteria were observed to be $25 \mu \mathrm{g} / \mathrm{mL}$, where no activity was observed against $B$. subtilis, S. typhimurium, $S$. infantis, $E$. faecalis and $C$. albicans.

Some studies were also previously studied the activity of $U$. dioica, $R$. sativus and $P$. granatum against several microorganisms. But only a minute amount of them are the antimicrobial activity of seed oils.

Kan et al. (2009) studied U. dioica seed oils and determined the antimicrobial activity and the fatty acid profile too. The yield percentage in this study was $22.59 \%$, where $30 \%$ in our study. This difference could possibly base on the oil extraction method used. Kan et al. (2009) extracted the oil from seeds by using Soxhlet apparatus with $n$ hexane as an extraction solvent, but we have extracted oils by direct cold pressing.

Kan et al. (2009) determined the activity of $U$. dioica seed oil against 10 microorganisms. They have found a MIC value of $32 \mu \mathrm{g} / \mathrm{mL}$ for both $S$. aureus ATCC 25923 and E. faecalis ATCC 29212. In our study we determined a $25 \mu \mathrm{g} / \mathrm{mL}$ of MIC value for the same strains. This difference is possibly related to higher yield due to application of cold pressing. This method might be effective in increasing the active substances during extraction.

On the other hand, they also tested the antimicrobial activity of $U$. dioica seed oil against B. subtilis, C. albicans, E. coli, K. pneumoniae and $P$. aeruginosa, and the MIC values for these microorganisms were identified to be $32 \mu \mathrm{g} / \mathrm{mL}, 16 \mu \mathrm{g} / \mathrm{mL}, 16$ $\mu \mathrm{g} / \mathrm{mL}, \quad 16 \mu \mathrm{g} / \mathrm{mL}$ and $32 \mu \mathrm{g} / \mathrm{mL}$ respectively.

In our study we found the MIC values for these microorganisms as $25 \mu \mathrm{g} / \mathrm{mL}$ for $B$. subtilis, $12.5 \mu \mathrm{g} / \mathrm{mL}$ for C. albicans, 25 $\mu \mathrm{g} / \mathrm{mL}$ for $E$. coli, $12.5 \mu \mathrm{g} / \mathrm{mL}$ for $K$. pneumoniae and no MIC value for $P$. aeruginosa. The main reason for this difference depends on the difference in the strains used in both studies. 
As for other antimicrobial studies of different type of $U$. dioica extracts, such as leaf and stem extracts, previously presented that this plant is active against $C$. albicans, $S$. enteritidis, Salmonella gallinarum, Salmonella agalactiae, K. pneumoniae, S. aureus, $\quad P$. aeruginosa, Lactobacillus plantarum and E. coli (Kelet, Bakırel, Ak \& Alpmar, 2001; Gülçin, Kührevioğlu, Oktay \& Büyükokuroğlu, 2004; Kukrić et al., 2012). But since the extracts are different it is no use to compare these results with our results.

Some researchers also presented the activity of $R$. sativus in the literature, but nearly all of them are the activity of crude juices or extracts of different parts such as leaves, seeds and roots, since both the juices and leaves, seeds and roots are known to be used as medicine all over the world (Chopra, Nayar \& Chopra, 1986; Kritikar and Basu, 1987; Bin Sina, 1987; Ahmad, Hasan, Chishti \& Ahmad, 2012).

Table 3. Disk diffusion test results for $5 \mu \mathrm{L}$ and $15 \mu \mathrm{L}$ of cold press oils obtained from $U$. dioica, $R$. sativus and P. granatum seeds (Inhibition zones in $\mathrm{mm}$ ).

\begin{tabular}{lcccccc}
\hline & \multicolumn{2}{c}{ U. dioica } & \multicolumn{2}{c}{ R. sativus } & \multicolumn{2}{c}{ P. granatum } \\
\hline & $5 \mu \mathrm{L}$ & $15 \mu \mathrm{L}$ & $5 \mu \mathrm{L}$ & $15 \mu \mathrm{L}$ & $5 \mu \mathrm{L}$ & $15 \mu \mathrm{L}$ \\
\hline B. subtilis & - & 7 & 8 & 9 & - & - \\
\hline C. albicans & 8 & 9 & 10 & 11 & - & - \\
\hline E. aerogenes & 8 & 9 & 9 & 10 & - & 7 \\
\hline E. faecalis & 7 & 8 & 9 & 10 & - & - \\
\hline E. faecium & - & 7 & 8 & 10 & 7 & 8 \\
\hline E. coli & 7 & 8 & 7 & 8 & 7 & 8 \\
\hline K. pneumoniae & 8 & 9 & 9 & 10 & 7 & 8 \\
\hline$P$. aeruginosa & - & 7 & 7 & 8 & - & 7 \\
\hline$P$. fluorescens & 7 & 8 & 9 & 10 & 7 & 8 \\
\hline S. enteritidis & 7 & 8 & 8 & 9 & 7 & 8 \\
\hline S. infantis & 7 & 8 & 9 & 10 & - & - \\
\hline S. kentucky & 8 & 9 & 9 & 10 & - & 7 \\
\hline S. typhimurium & 7 & 9 & 8 & 9 & - & - \\
\hline S. aureus & 7 & 8 & 8 & 10 & 7 & 8 \\
\hline S. epidermidis & - & - & 8 & 9 & - & 7 \\
\hline “.' implies no effect. & & & & & &
\end{tabular}

Table 4. The results for standard antibiotic disks (Inhibition zones in $\mathrm{mm}$ )

\begin{tabular}{|c|c|c|c|c|c|c|c|c|c|c|c|c|}
\hline & CFZ & CLI & CAM & CPR & AMC & SXT & CRO & GEN & AMP & CEF & CXM & VAN \\
\hline B. subtilis & 44 & 34 & 37 & 36 & 56 & 42 & 38 & 30 & 41 & 36 & 44 & 20 \\
\hline C. albicans & - & - & - & - & - & - & - & - & - & - & - & - \\
\hline E. aerogenes & 14 & - & 26 & 30 & 9 & 24 & 21 & 23 & - & - & 16 & - \\
\hline E. faecalis & 14 & - & 19 & 19 & 28 & 29 & - & 13 & 14 & - & - & 15 \\
\hline E. faecium & 40 & 30 & 11 & 28 & 43 & 34 & 31 & 28 & 32 & 24 & 33 & 26 \\
\hline E. coli & 18 & - & 22 & - & 16 & 12 & - & 20 & 6 & 6 & 6 & 6 \\
\hline K. pneumoniae & - & - & 22 & 30 & 9 & 6 & 6 & 22 & 6 & 6 & 6 & - \\
\hline P. aeruginosa & - & - & 9 & 28 & - & - & - & 15 & - & - & - & - \\
\hline P. fluorescens & 10 & 8 & 22 & 19 & 26 & 26 & - & 12 & 14 & - & - & 16 \\
\hline S. enteritidis & 23 & - & 28 & 36 & 28 & 31 & 27 & 24 & 16 & - & 16 & - \\
\hline S. infantis & 22 & - & 28 & 24 & 26 & 24 & 26 & 24 & 14 & - & 17 & - \\
\hline S. kentucky & 22 & - & 29 & 34 & 26 & 27 & 30 & 13 & 15 & - & 19 & - \\
\hline S. typhimurium & 22 & - & 27 & 35 & 26 & 21 & 27 & 23 & 13 & - & 14 & - \\
\hline S. aureus & 31 & 24 & 21 & 22 & 30 & 27 & 16 & 24 & 25 & 22 & 29 & 16 \\
\hline S. epidermidis & 37 & 35 & 33 & 34 & 45 & 32 & 26 & 25 & 24 & 26 & 32 & 21 \\
\hline
\end{tabular}

"_": No activity observed, CFZ: Cefazolin, CLI: Clindamycin, CAM: Chloramphenicol, CPR: Ciprofloxacin, AMC: Amoxicillin/Clavulanic acid, SXT: Sulfamethoxazole/Trimethoprim, CRO: Ceftriaxone, GEN: Gentamicin, AMP: Ampicillin, CEF: Cephalothin, CXM: Cefuroxime, VAN: Vancomycin 
Table 5. MIC values $(\mu \mathrm{g} / \mathrm{mL})$ for $U$. dioica, $R$. sativus and $P$. granatum

\begin{tabular}{|c|c|c|c|}
\hline & U. dioica & R. sativus & P. granatum \\
\hline B. subtilis & 25 & 12.5 & - \\
\hline C. albicans & 12.5 & 12.5 & - \\
\hline E. aerogenes & 12.5 & 12.5 & 25 \\
\hline E. faecalis & 25 & 12.5 & - \\
\hline E. faecium & 25 & 12.5 & 25 \\
\hline E. coli & 25 & 25 & - \\
\hline K. pneumoniae & 12.5 & 12.5 & 25 \\
\hline P. aeruginosa & - & 25 & - \\
\hline P. fluorescens & 25 & 12.5 & 25 \\
\hline S. enteritidis & 25 & 12.5 & 25 \\
\hline S. infantis & 25 & 12.5 & - \\
\hline S. kentucky & 12.5 & 12.5 & 25 \\
\hline S. typhimurium & 12.5 & 12.5 & - \\
\hline S. aureus & 25 & 12.5 & 25 \\
\hline S. epidermidis & - & 12.5 & 25 \\
\hline
\end{tabular}

Crude juice of $R$. sativus was found to have antimicrobial activity on $E$. coli, Pseudomonas pyocyaneus, $P$. aeruginosa, Salmonella typhi, Salmonella thyphosa and B. subtilis (Abdou, Abou-Zeid, El-Sherbeeny \& Abou-El-Gheat, 1972; Caceres, 1987).

Although it was previously mentioned that the $R$. sativus seeds contain quite high oil (Gutiérrez and Perez, 2004), there aren't much noteworthy studies about the antimicrobial activity of the oil obtained from radish seeds according to the best of our knowledge. Thus, it is not possible to compare our results regarding the antimicrobial activity of $R$. sativus to any other previous studies. Alternatively, one research conducted (Ahmad, Hasan, Chishti \& Ahmad, 2012) could possibly extracted several fatty acids and essential oils from $R$. sativus seeds due to the extraction solvents used. They have used aqueous cold and hot solvents, benzene, chloroform, ethyl acetate, methanol and ethanol, and they applied agar well diffusion test to determine the antimicrobial activity against Salmonella paratyphi ATCC 9150, S. typhi ATCC 25241, Shigella sonnie ATCC 25931, S. aureus ATCC 25923, P. aeruginosa ATCC 27853, Proteus vulgaris ATCC 6380, K. pneumoniae ATCC 27736 and E. coli ATCC 25922. As a result they have found that the diameter of inhibition zones for $E$. coli ATCC 25922 are $9.0 \pm 1.4 \mathrm{~mm}, 10.0 \pm 0.5$ $\mathrm{mm}, 12.0 \pm 0.5 \mathrm{~mm}, 12.5 \pm 0.7 \mathrm{~mm}, 12.5 \pm$ $0.7 \mathrm{~mm}$ and $14.5 \pm 0.7 \mathrm{~mm}$ for ethyl acetate, chloroform, aqueous hot, methanol, benzene and ethanol extracts respectively. In our study we have found $8.0 \mathrm{~mm}$ inhibition zone as the highest for $R$. sativus oil against $E$. coli ATCC 25922.

On the other hand, Ahmad, Hasan, Chishti and Ahmad (2012) have observed that the diameter of inhibition zones for $S$. aureus ATCC 25923 are $9.0 \pm 0.5 \mathrm{~mm}, 9.0 \pm$ $0.5 \mathrm{~mm}, 10.0 \pm 0.5 \mathrm{~mm}, 12.0 \pm 0.5 \mathrm{~mm}, 13.5$ $\pm 0.7 \mathrm{~mm}, 18.0 \pm 0.5 \mathrm{~mm}$ and $19 \pm 7.0 \mathrm{~mm}$ for aqueous cold, benzene, chloroform, aqueous hot, methanol, ethyl acetate and ethanol extracts respectively. In our study we have found $10 \mathrm{~mm}$ inhibition zone as the highest inhibition zone for $R$. sativus oil against $S$. aureus ATCC 25923.

There are three main reasons for these differences; (1) methods used to identify antimicrobial activity are different, namely disk diffusion test and agar well diffusion assay, (2) extraction method, therefore the composition of the extracts, are different and (3) the amount of extract tested in agar well diffusion assay was about 13 fold higher than our study.

There are more than hundred researches about the activities of $P$. granatum's different parts such as fruit, fruit peels, seeds, etc., by using different extraction solvents (Singh, Chidambara Murthy \& Jayaprakasha, 2002; Naz, Siddiqi, Ahmad, Rasool \& Sayeed, 2007; Reddy, Gupta, Jacob, Khan \& Ferreira, 2007; Altuner, 2011; Devi, Singh \& Bhatt, 2011). 
As for $U$. dioica and $R$. sativus there are not much studies about the antimicrobial activity of $P$. granatum seed oils.

In one of the studies Rustaiyan, Samiee, Kurabaslu and Taghizadeh et al. (2013) tested the antimicrobial activity of pomegranate seed oil against four microorganisms, namely $E$. coli ATCC 25922, S. aureus ATCC 25923, B. subtilis and Saccharomyces cerevisiae ATCC 2365 by disk diffusion test. However, they didn't observe any antimicrobial activity against these four microorganisms. Instead we observed $8.0 \mathrm{~mm}$ inhibition zone as the highest inhibition zone against both for $S$. aureus ATCC 25923 and E. coli ATCC 25922. This difference could possibly due to the difference of oil extraction processes used in these two studies. Rustaiyan et al. (2013) used hexane as extraction solvent and applied solvent extraction method previously described by AOAC (1990). This results may show that cold-pressing technique extracts antimicrobial substances more than solvent extraction method.

In another study Tanveer et al. (2016) studied the antimicrobial activity of pomegranate peel and seed extracts against E. feacalis, E. coli, $S$. aureus and $P$. aeruginosa by disk diffusion method. They observed inhibition zones of $7.12 \mathrm{~mm}$ for $E$. coli, $6.12 \mathrm{~mm}$ for $P$. aeruginosa, $6.25 \mathrm{~mm}$ for $S$. aureus and $7.12 \mathrm{~mm}$ for E. feacalis as a result of applying seed water extracts. In our study we observed higher inhibition zones for all microorganisms except for $E$. feacalis. This difference can be related with the difference in extraction method.

According to the results all three seed oils presented antimicrobial activity against $S$. kentucky, P. aeruginosa, E. coli, E. faecium, $E$. aerogenes, K. pneumoniae, $P$. fluorescens, $S$. enteritidis and $S$. aureus.

Intensive care units (ICU) are very serious places for especially nosocomial infections (NI). Thus, antimicrobial activity against any microorganism responsible for nosocomial infections in ICU would be very important.

$E$. aerogenes is accepted as one of the Intensive Care Unit pathogens that will lead to significant mortality and morbidity. On the other hand the infection management for this microorganism is complicated since it may generate resistance to the drugs used against (Hidron, Edwards \& Patel, 2008).

$P$. aeruginosa is accepted as a frequent reason for NI, especially in patients, which are critically ill and hospitalized. It is known that infections related to $P$. aeruginosa can be complicated and life-threatening (Obritsch, Fish, MacLaren \& Jung, 2005).

$S$. aureus is one of other pathogen that is also responsible for NI in ICU (Richards, Edwards, Culver \& Gaynes, 1999).

It was previously proven that Gram (-) microorganisms are resistant to antibiotics than Gram (+) microorganisms (Nikaido, 1998; Faucher and Avril, 2002). $K$. pneumoniae is one of the important Gram (-) strains, which also cause some severe infections in ICU (Villegas and Quinn, 2004).

Although in our study a high activity wasn't observed against $P$. aeruginosa, $S$. aureus, E. aerogenes and $K$. pneumoniae compared to standard antibiotic disks, the results can be accepted as noteworthy since all these pathogens are important in causing NI in ICU.

The composition of the oils extracted from $U$. dioica, $R$. sativus and $P$. granatum directly affects their antimicrobial activity.

According to GC-MS results 9,12Octadecadienoic acid is found in all oil extracts with percentage of $38.87 \%, 8.30 \%$ and $5.75 \%$ in $U$. dioica, $R$. sativus and $P$. granatum respectively.

9,12-Octadecadienoic acid, which is also known as linoleic acid and its antimicrobial activity was defined in several previous studies. Tsuchida and Morishida (1995) determined the antimicrobial activity of linoleic acid by using several Gram negative and Gram positive strains. In this study it was presented that Gram positive strains are generally susceptible to linoleic acid.

9-octadecenoic acid is found in two of the oil extracts with percentage of $14.34 \%$ and $6.42 \%$ in $U$. dioica and $P$. granatum respectively.

9-octadecenoic acid is also known as oleic acid and several studies showed that it has potential of possessing antibacterial and antifungal activity (Kabara, Swieczkowski, Conley \& Tuant, 1972; Dilika, Bremner \& Meyer, 2000; McGraw, Jager \& Van Staden, 
2002; Seidel and Taylor, 2004). Dilika, Bremner and Meyer (2000) presented that oleic acids isolated from Helichrysum pedunculatum was active against several Gram (+) bacteria.

Hexadecanoic acid (palmitic acid) is found $4.32 \%$ in $U$. dioica oil according to GC-MS results. The antimicrobial activity of palmitic acid is also shown in some previous studies (Glover, Whittemore \& Bryant, 1997; Risk, Harrison \& Lewis, 1997; Bazes et al., 2009). A noteworthy activity of palmitic acid against both fungi and bacteria were previously reported (Altieri, Cardillo, Bevilacqua \& Singaglia, 2007; Liu et al., 2008; Huang, George \& Ebersole, 2011).

13-docosenoic acid (erucic acid) is found $25.40 \%$ of $R$. sativus oil according to GC-MS results. Bailey et al (1989) showed the activity of some erucic acid-glycolic acid derivatives against Candida utilis, E. coli, S. aureus and Penicillum notatum.

6-octadecenoic acid, which is known as petroselinic acid, is found $17.22 \%$ of $R$. sativus oil according to GC-MS results. According to some previous researches petroselinic acid has a considerable antimicrobial activity against several bacteria, yeast and mold species (Placek, 1963).

It is obvious that all oils extracted from $U$. dioica, $R$. sativus and $P$. granatum contains several fatty acids which are active as antimicrobial agents. The antimicrobial activity of these oils could be related to their fatty acid composition.

As a result, it can be concluded that there is a clear antimicrobial activity of all three seed oils against $E$. aerogenes, E. faecium, $E$. coli, $K$. pneumoniae, $P$. aeruginosa, $P$. fluorescens, S. enteritidis, S. kentucky and $S$. aureus.

The antimicrobial activity of all oils against $E$. aerogenes, $P$. aeruginosa, $S$. aureus and $K$. pneumoniae can be accepted as noteworthy since all these pathogens are important in causing NI in ICU.

On the other hand, the composition of the oils are promising for further researches, since they contain several fatty acids having antimicrobial nature. But further researches are needed to be conducted in order to analyse their activity mechanisms in details.

\section{References}

Abbasi, A.M, Khan, M.A., Ahmad, M., Jahan, S. \& Sultana, S. (2010). Ethnopharmacological application of medicinal plants to cure skin diseases and in folk cosmetics among the tribal communities of North-West Frontier Province. Journal of Ethnopharmacology, 128, 322-335.

Abdou, I.A., Abou-Zeid, A.A., El-Sherbeeny, M.R. \& Abou-El-Gheat, Z.H. (1972). Antimicrobial activities of Allium sativum, Allium cepa, Raphanus sativus, Capsicum frutescens, Eruca sativa, Allium kurrat on bacteria. Plant Foods for Human Nutrition, 22(1), 29-35.

Ahmad, F., Hasan, I., Chishti, D.K. \& Ahmad, H. (2012). Antibacterial activity of Raphanus sativus Linn. seed extract. Global Journal of Medical Research, 12(11), 25-34.

Altieri, C., Cardillo, D., Bevilacqua, A. \& Singaglia, M. (2007). Inhibition of Aspergillus ssp. and Penicillium spp. by fatty acids and their monoglycerides. Journal of Food Protection, 70, 1206-1212.

Altuner, E.M., Akata, I. \& Canli, K. (2012a). In vitro antimicrobial screening of Bovista nigrescens (Pers.). Kastamonu University Journal of Forestry Faculty, 12, 90-96.

Altuner, E.M., Akata, I. \& Canli, K. (2012b). In vitro antimicrobial screening of Cerena unicolor (Bull.) Murrill (Polyporaceae Fr. Ex Corda). Fresenius Environmental Bulletin, 21, 3704-3710.

Altuner, E.M. \& Akata, I. (2010). Antimicrobial activity of some macrofungi extracts. Sakarya Üniversitesi Fen Bilimleri Enstitüsü Dergisi, 14(1), 45-49.

Altuner, E.M., Canli, K. \& Akata, I. (2014). Antimicrobial screening of Calliergonella cuspidata, Dicranum polysetum and Hypnum cupressiforme. Journal of Pure and Applied Microbiology, 8(1), 539-545.

Altuner, E.M. \& Canli, K. (2012). In vitro antimicrobial screening of Hypnum andoi A.J.E. Sm. Kastamonu University Journal of Forestry Faculty, 12, 97-101.

Altuner, E.M., Cetin, B. \& Cökmüs, C. (2010a). Antimicrobial activity of Tortella tortulosa (Hedw.) Limpr. extracts, Kastamonu Üniversitesi Orman Fakültesi Dergisi, 10(2), 111-116.

Altuner, E.M., Cetin, B. \& Cökmüs, C. (2010b). Antimicrobial Screening of Some Mosses Collected From Anatolia. Pharmacognosy Magazine, 6 (22), 56.

Altuner, E.M. \& Çetin, B. (2009). Antimicrobial activity of Thuidium delicatulum (Bryopsida) extracts. Kafkas Üniversitesi Fen Bilimleri Enstitüsü Dergisi, 2(2), 85-92. 
Altuner, E.M., Ceter, T. \& Islek, C. (2010). Investigation of antifungal activity of Ononis spinosa L. ash used for the therapy of skin infections as folk remedies. Mikrobiyoloji Bülteni, 44(4), 633-639.

Altuner, E.M., Ceter, T., Demirkapi, D., Ozkay, K., Hayal, U. \& Eser, G. (2011a). Investigation on antimicrobial effects of some lichen species collected from Kastamonu region. Communications Faculty of Sciences De La Faculte Des Sciences University of Ankara Series C, 23(1-2), 21-31.

Altuner, E.M., Ceter, T., Bayar, E., Aydin, S., Arici, F., Suleymanoglu, G. \& Edis, A. (2011b). Investigation on antimicrobial effects of some moss species collected from Kastamonu region, Communications Faculty of Sciences De La Faculte Des Sciences University of Ankara Series C, 23(1-2), 33-43.

Altuner, E.M. (2011). Investigation of antimicrobial activity of Punica granatum L. fruit peel ash used for protective against skin infections as folk remedies especially after male circumcision. African Journal of Microbiology Research, 5(20), 3339-3342.

Andrews, J.M. (2003). BSAC standardized disc susceptibility testing method (version 6). Journal of Antimicrobial Chemotherapy, 60, 20-41.

AOAC. (1990). Official methods of analysis. 15th ed. Virginia: Association of Official Analytical Chemists, Inc.

Ates, D.A. \& Erdogrul, O.T. (2003). Antimicrobial activities of various medicinal and commercial plant extracts. Turkish Journal of Biology, 27, 157-162.

Bailey, A.V., De Lucca, II A.J., Moreau, J.P. (1989). Antimicrobial properties of some erucic acid-glycolic acid derivatives. JAOCS, 66(7), 932-934.

Balouiri, M., Sadiki, M. \& Ibnsouda, S.K. (2016). Methods for in vitro evaluating antimicrobial activity: A review. Journal of Pharmaceutical Analysis, 6(2), 71-79.

Bazes, A., Silkina, A., Douzenel, P., Faÿ, F., Kervarec, N., Morin, D., Berge, J.P. \& Bourgougnon, N. (2009). Investigation of the antifouling constituents from the brown alga Sargassum muticum (Yendo) Fensholt. Journal of Applied Phycology, 21, 395-403.

Bin Sina, A.A. (1987). Al-qanun fi'-tib Book II. New Delhi: Institute of history of medicine and medical research.

Caceres, A. (1987). Screening on antimicrobial activity of plants popular in Guatemala for the treatment of dermatomucosal diseases. Journal of Ethnopharmacology, 20, 223-237.

Canlı, K., Akata, I. \& Altuner, E.M. (2016). In vitro antimicrobial activity screening of
Xylaria hypoxylon. African Journal of Traditional, Complementary and Alternative Medicines, 13(4), 42-46.

Canlı, K., Altuner, E.M., Akata, I., Türkmen, Y. \& Üzek, U. (2016). In vitro antimicrobial screening of Lycoperdon lividium and determination of the ethanol extract composition by gas chromatography/mass spectrometry. Bangladesh Journal of Pharmacology, 11(2), 389-394.

Canlı, K., Altuner, E.M. \& Akata, I. (2015). Antimicrobial screening of Mnium stellare. Bangladesh Journal of Pharmacology, 10:321-325.

Canlı, K., Çetin, B., Altuner, E.M., Türkmen, Y., Üzek, U. \& Dursun, H. (2014). In vitro antimicrobial screening of Hedwigia ciliata var. leucophaea and determination of the ethanol extract composition by gas chromatography/mass spectrometry (GC/MS). Journal of Pure and Applied Microbiology, 8(4), 2987-2998.

Canlı, K., Şimşek, Ö., Yetgin, A. \& Altuner, E.M. (2017). Determination of the chemical composition and antimicrobial activity of Frankenia hirsuta, Bangladesh Journal of Pharmacology, 12(4), 463-469.

Canl1, K., Yetgin, A. Akata, I. Altuner, E.M. (2016a). In vitro antimicrobial activity of Angelica sylvestris roots. International Journal of Biological Sciences, 1(1), 1-7.

Canlı, K., Yetgin, A., Akata, I. \& Altuner, E.M. (2016b). In vitro antimicrobial screening of Aquilaria agallocha roots. African Journal of Traditional, Complementary and Alternative Medicines, 13(5), 178-181.

Canlı, K., Yetgin, A., Akata, I. \& Altuner, E.M. (2016c). In vitro antimicrobial activity screening of Rheum rhabarbarum roots. International Journal of Pharmaceutical Sciences Invention, 5(2), 1-4.

Canlı, K., Yetgin, A., Akata, I. \& Altuner, E.M. (2017a). Antimicrobial activity and chemical composition screening of Anacyclus pyrethrum root, Indian Journal of Pharmaceutical Education and Research, 51(3s), 244-248.

Canlı, K., Yetgin, A., Akata, I. \& Altuner, EM. (2017b). Antimicrobial activity and chemical composition screening of Epilobium montanum root. Indian Journal of Pharmaceutical Education and Research, 51(3s), 239-243.

Chopra, R.N., Nayar, S.L. \& Chopra, I.C. (1986). Glossary of Indian medicinal plants (including the supplements). New Delhi: Council of Scientific and Industrial Research.

Cos, P., Vlietinck, A.J., Vanden Berghe, D. \& Maes, L. (2006). Anti-infective potential of 
natural products: How to develop a stronger in vitro 'proof-of-concept'. Journal of Ethnopharmacology, 106, 290-302.

Devi, A., Singh, V. \& Bhatt, A.B. (2011). Comparative antibacterial study of different extract of pomegranate and its wild variety. IJPSR, 2(10), 2647-2650.

Dilika, F., Bremner, P.D. \& Meyer, J.J. (2000). Antibacterial activity of linoleic and oleic acids isolated from Helichrysum pedunculatum: a plant used during circumcision rites. Fitoterapia, 71(4), 450452.

Faucher, J.L. \& Avril, J.L. (2002). Bactériologie générale et médicale. Tome 1. Ellipses (Ed.), Paris.

Glover, D.E., Whittemore, M.S. \& Bryant, S.D. (1997). Methods and compositions for controlling biofouling using polyglycol fatty acid esters. International Patent Application, WO97/11912.

Gutiérrez, R.M.P. \& Perez, R.L. (2004). Raphanus sativus (radish): Their chemistry and biology. The Scientific World Journal, 4, 811-837.

Gülçin, I., Kührevioğlu, O.I., Oktay, M. \& Büyükokuroğlu, M.E. (2004). Antioxidant, antimicrobial, antiulcer, and analgesic activities of nettle (Urtica dioica L.). Journal of Ethnopharmacology, 90, 205-215.

Hammer, K.A., Carson, C.F. \& Riley, T.V. (1999). Antimicrobial activity of essential oils and other plant extracts. Journal of Applied Microbiology, 86, 985-990.

Health Beckon. 17 Amazing Benefits and Uses of Pomegranate Seed Oil, (2014). https://www.healthbeckon.com/pomegranateseed -oil-benefits/.

Hidron, A.I., Edwards, J.R. \& Patel, J. (2008). NHSN annual update: antimicrobial-resistant pathogens associated with healthcareassociated infections: annual summary of data reported to the National Healthcare Safety Network at the Centers for Disease Control and Prevention, 2006-2007. Infection Control \& Hospital Epidemiology, 29, 996-1011.

Huang, C.B., George, B. \& Ebersole, J.L. (2011). Antimicrobial activity of $n-6, n-7$ and n-9 fatty acids and their esters for oral microorganisms. Archives of Oral Biology, 55, 555-560.

Ilhan, S., Savaroğlu, F., Çolak, F., Iscen, C.F. \& Erdemgil, F.Z. (2006). Antimicrobial activity of Palustriella commutata (Hedw.) Ochyra extracts (Bryophyta). Turkish Journal of Biology, 30, 149-152.

Kabara, J.J., Swieczkowski, D.M., Conley, A.J. \& Tuant, J.P. (1972). Fatty acids and derivatives as antimicrobial agents. Antimicrobial Agents and Chemotherapy., 2, 23-28.,

Kan, Y., Orhan, I., Koca, U., Özçelik, B., Aslan, S., Kartal, M. \& Küsmenoğlu, S. (2009). Fatty acid profile and antimicrobial effect of the seed oils of Urtica dioica and U. pilulifera. Turkish Journal of Pharmaceutical Sciences, 6(1), 21-30.

Kelet, O., Bakırel, T., Ak, S. \& Alpmar, A. (2001). The antibacterial activity of some plants used for medicinal purposes against pathogens of veterinary importance. Folia Veterinaria, 45, 243-246.

Kew Science. Urtica dioica L., (2017a). http://powo.science.kew.org/taxon/urn:lsid:ipn i.org:names:260630-2.

Kew Science. Raphanus raphanistrum subsp. sativus L. Domin, (2017b). http://powo.science.kew .org/taxon/urn:lsid:ipni.org:names:771593051.

Kritikar, R.K. \& Basu, B.D. (1987). Indian medicinal Plants. Vol. I. 2nd. ed. International Book Distributors, Dehradun, India.

Kukrić, Z.Z., Topalić-Trivunović, L.N., Kukavica, B.M., Matoš, S.B., Pavičić, S.S., Boroja, M.M. \& Savić, A.V. (2012). Characterization of antioxidant and antimicrobial activities of nettle leaves (Urtica dioica L). APTEFF, 43, 1-342.

Liu, S., Weibin, R., Jing, L., Hua, X., Jingan, W., Yubao, G. \& Jingguo, W. (2008). Biological control of phytopathogenic fungi by fatty acids. Mycopathologia, 166, 93-102.

McGraw, L.J., Jager, A.K. \& Van Staden, J. (2002). Isolation of antibacterial fatty acids from Schotia brachypetala. Fitoterapia, 73, 431-433.

Naz, S., Siddiqi, R., Ahmad, S., Rasool, S.A. \& Sayeed, S.A. (2007). Antibacterial activity directed isolation of compounds from Punica granatum. Journal of Food Science, 72(9), 341-345.

Nikaido, H. (1998). Antibiotic resistance caused by gram-negative multidrug efflux pumps. Clinical Infectious Diseases, 27, 32-41.

Obritsch, M.D., Fish, D.N., MacLaren, R. \& Jung, R. (2005). Nosocomial infections due to multidrug-resistant Pseudomonas aeruginosa: epidemiology and treatment options. Pharmacotherapy, 25(10), 1353-1364.

Okeke, I.N., Laxmaninarayan, R., Bhutta, Z.A., Duse, A.G., Jenkins, P., O’Brien, T.F., Pablos-Mendez, A. \& Klugman, K.P. (2005). Antimicrobial resistance in developing countries. Part 1: recent trends and current status. Lancet Infectious Diseases, 5, 481-493.

Özkinali, S., Şener, N., Gür, M., Güney, K. \& Olgun Ç. (2017). Antimicrobial activity and 
chemical composition of Coriander \& Galangal essential oil. Indian Journal of Pharmaceutical Education and Research, 51, 221-224.

Placek, L.L. (1963). Review on petroselinic acid and its derivativees. Journal of the American Oil Chemists' Society, 40, 319-329.

Reddy, M.K., Gupta, S.K., Jacob, M.R., Khan, S.I. \& Ferreira, D. (2007). Antioxidant, antimalarial and antimicrobial activities of tannin-rich fractions, ellagitannins and phenolic acids from Punica granatum L. Planta Medica, 73(5), 461-467.

Richards, M.J., Edwards, J.R., Culver, D.H. \& Gaynes, R.P. (1999). Nosocomial infections in medical intensive care units in the United States: National Nosocomial Infections Surveillance System. Critical Care Medicine, 27, 887-892.

Rieger, M. Pomegranate tree (Punica granatum 1.) taxonomy, (2017). www.fruitcrops.com/pomegr anate-punica-granatum-1/.

Risk, M., Harrison, P. \& Lewis, J. 1997. Wood preserving composition. International Patent Application. WO 97/34747.

Rustaiyan, A., Samiee, K., Kurabaslu, S.E. \& Taghizadeh, M. (2013). Extraction, analysis and study of antioxidant activity and total phenolic of pomegranate (Punica granatum L.) seed oil from four different regions of Iran (Yazd, Saveh, Kashan and Varamin). Nature and Science, 11(2), 14-18.

Seidel, V. \& Taylor, P.W. (2004). In vitro activity of extracts and constituents of Pelagonium against rapidly growing mycobacteria. International Journal of Antimicrobial Agents, 23, 613-619.

Singh, R.P., Chidambara Murthy, K.N. \& Jayaprakasha, G.K. (2002). Studies on the antioxidant activity of pomegranate (Punica granatum) peel and seed extracts using in vitro models. Journal of Agricultural and Food Chemistry, 50(1), 81-86.

Syed, G.W., Syed, A.S. \& Oh, L.A. (2010). Risk evaluation under various speculations of antibiotic usage; A cohort survey among outpatients of Pinang, Malaysia. European Journal of General Medicine, (7), 303-309.

Tanveer, A., Farooq, U., Akram, K., Shafi, A., Sarfraz, F. \& Rehman, H. 2016. Antibacterial potential of pomegranate peel and seed extracts against food borne pathogens. Asian Journal of Agriculture and Biology, 4(3), 6064.

Tsuchida, M. \& Morishlta, Y. (1995). Antibacterial activity and bacterial degradation of linoleic acid hydroperoxide. Bifidobacteria Microflora, 14, 67-74.
Villegas, M.V. \& Quinn, J.P. (2004). An update on antibiotic-resistant gram-negative bacteria. Infections in Medicine, 21, 595-599.

WHO. (2007). The world health report 2007: A safer future: global public health security in the 21 st century. 